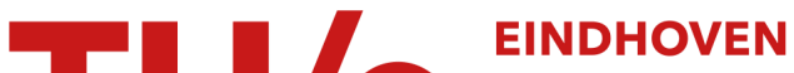 \\ UNIVERSITY OF \\ TECHNOLOGY
}

\section{Solid-state deformation of trans-1,4-polybutadiene}

\section{Citation for published version (APA):}

Aerle, van, N. A. J. M., Lemstra, P. J., Kanamoto, T., \& Bastiaansen, C. W. M. (1991). Solid-state deformation of trans-1,4-polybutadiene. Polymer, 32(1), 34-38. https://doi.org/10.1016/0032-3861(91)90558-Z

DOI:

10.1016/0032-3861(91)90558-Z

Document status and date:

Published: 01/01/1991

\section{Document Version:}

Publisher's PDF, also known as Version of Record (includes final page, issue and volume numbers)

\section{Please check the document version of this publication:}

- A submitted manuscript is the version of the article upon submission and before peer-review. There can be important differences between the submitted version and the official published version of record. People interested in the research are advised to contact the author for the final version of the publication, or visit the $\mathrm{DOI}$ to the publisher's website.

- The final author version and the galley proof are versions of the publication after peer review.

- The final published version features the final layout of the paper including the volume, issue and page numbers.

Link to publication

\section{General rights}

Copyright and moral rights for the publications made accessible in the public portal are retained by the authors and/or other copyright owners and it is a condition of accessing publications that users recognise and abide by the legal requirements associated with these rights.

- Users may download and print one copy of any publication from the public portal for the purpose of private study or research.

- You may not further distribute the material or use it for any profit-making activity or commercial gain

- You may freely distribute the URL identifying the publication in the public portal.

If the publication is distributed under the terms of Article 25fa of the Dutch Copyright Act, indicated by the "Taverne" license above, please follow below link for the End User Agreement:

www.tue.nl/taverne

Take down policy

If you believe that this document breaches copyright please contact us at:

openaccess@tue.nl

providing details and we will investigate your claim. 


\title{
Solid-state deformation of trans-1,4-polybutadiene
}

\author{
N. A. J. M. van Aerle and P. J. Lemstra \\ Department of Polymer Technology, Eindhoven University of Technology, \\ PO Box 513, 5600 MB Eindhoven, The Netherlands
}

T. Kanamoto

Department of Applied Chemistry, Science University of Tokyo, Kagurazaka, Shinjuku-Ku. Tokyo 162, Japan

and C. W. M. Bastiaansen*

DSM Research, PO Box 18, 6160 MD Geleen, The Netherlands

(Received 11 October 1989; accepted 10 January 1990)

\begin{abstract}
The uniaxial deformation behaviour of trans-1,4-polybutadiene was investigated. Trans-1,4-polybutadiene exhibits a solid-solid phase transition to a mobile pseudo-hexagonal, conformational disordered (condis), crystal structure at a temperature of approximately $65^{\circ} \mathrm{C}$. Trans-1,4-polybutadiene cannot be deformed to high draw ratios via tensile drawing in the pseudo-hexagonal condis phase. Using coextrusion, trans-1,4-polybutadiene can be deformed, in the pseudo-hexagonal condis phase, to high (extrusion) draw ratios. Structures possessing a high degree of chain orientation in the extrusion direction and a strongly enhanced Young's modulus and tensile strength can be produced.
\end{abstract}

(Keywords: tensile drawing; solid-state extrusion; trans-1,4-polybutadiene; hexagonal phase; modulus; strength)

\section{INTRODUCTION}

High-strength and high-modulus polyethylene fibres can be produced using a variety of techniques comprising solution-spinning/drawing ${ }^{1-3}$, melt-spinning/drawing ${ }^{4-6}$ and solid-state deformation processes ${ }^{7-9}$. In these techniques a high degree of chain orientation/extension in one dimension is generated in linear polyethylenes by uniaxial deformation in the solid state. The mechanical properties of these highly oriented polyethylene structures are impressive, especially with respect to short-term modulus and tensile strength ${ }^{1-9}$.

In previous studies, attempts have been reported to reduce the long-term creep of oriented polyethylene fibres by introducing chemical crosslinks in the fibres ${ }^{10}$. It was shown that crosslinking of polyethylene fibres after ultra-drawing is rather difficult to achieve. In most cases, mainly chain scission occurred, which resulted in a reduced tensile strength. Crosslinking before ultradrawing, for example via electron beam irradiation, was used to improve the balance between crosslinking and chain scission ${ }^{11}$. However, the maximum attainable draw ratio and hence the modulus and tensile strength decrease with increasing crosslink density. Consequently one has to compromise between short-term (modulus, strength) and long-term (creep) properties ${ }^{11}$.

We started to investigate the deformation behaviour of polyalkenamers to produce crosslinked high-strength and high-modulus structures based on unsaturated polymers. In this study some preliminary results concerning the deformation behaviour of trans-1,4-polybutadiene are presented.

\footnotetext{
* To whom correspondence should be addressed

0032-3861/91/010034-05

(C) 1991 Butterworth-Heinemann Ltd.
}

\section{EXPERIMENTAL}

Trans-1,4-polybutadiene was synthesized at room temperature by polymerization of 1,3-butadiene using a $\mathrm{VCl}_{3} / \mathrm{Al}\left(\mathrm{C}_{2} \mathrm{H}_{5}\right)_{3}$ catalyst system ${ }^{12}$. The yield of the reaction was about $60 \%$. The viscosity-average molecular weight of the polymer is approximately $75 \mathrm{~kg} \mathrm{~mol}^{-1}$ (ref. 13). Infra-red analysis and ${ }^{13} \mathrm{C}$ n.m.r. indicated that the vinyl content of the polymer was approximately $0.9-1.2 \%$. No detectable amount of cis isomer could be observed.

Trans-1,4-polybutadiene (trans-1,4-PB) was dissolved in toluene, at a nominal polymer concentration of $0.2 \mathrm{wt} \%$, under $\mathrm{N}_{2}$ atmosphere at $90^{\circ} \mathrm{C}$. Prior to the dissolution procedure $2 \mathrm{wt} \%$ di-t-butyl-p-cresol was added to the polymer. After complete dissolution occurred, the solution was slowly cooled to $10^{\circ} \mathrm{C}$ and kept at this temperature for at least $12 \mathrm{~h}$. Single crystal mats were obtained by filtering the suspension of crystals, followed by drying in vacuo at $30^{\circ} \mathrm{C}$.

Melt-crystallized trans-1,4-polybutadiene films were prepared by compression moulding of single crystal mats at $160^{\circ} \mathrm{C}$ for $15 \mathrm{~min}$.

Melt-crystallized high-density polyethylene (HDPE) films were prepared by compression moulding of pellets at $180^{\circ} \mathrm{C}$ for $30 \mathrm{~min}$.

Tensile drawing at elevated temperature was performed on a Frank 81565 tensile tester equipped with an air oven. Dumbbell-shaped samples with an original length of $20 \mathrm{~mm}$ were drawn at a constant crosshead speed of $20 \mathrm{~mm} \mathrm{~min}^{-1}$.

HDPE billets with a diameter of $1 \mathrm{~cm}$ were prepared by compression moulding at $160^{\circ} \mathrm{C}$. The HDPE grades used were Alathon 7050 (DuPont, $M_{w}=58 \mathrm{~kg} \mathrm{~mol}^{-1}$ ) and JX-20 (Mitsubishi Petrochemical Co., $M_{w}=67 \mathrm{~kg} \mathrm{~mol}^{-1}$ ). 
The billets were split longitudinally into two halves. Strips, with a width of $1-2 \mathrm{~mm}$, were cut from the trans-1,4-PB single crystal mats and subsequently sandwiched in the centre of a split billet and coextruded, at various temperatures, through conical brass dies with an entrance angle of $20^{\circ}$ to nominal extrusion draw ratios (EDRs) ranging from 2 to 36 . The coextrusions were performed at a constant pressure of $10-150 \mathrm{MPa}$. The extrudates could be split easily into two halves again and a coextruded strip of trans-1,4-PB was obtained. The EDR of the samples was determined from the displacement of ink marks on the strips.

The Young's modulus and tensile strength of coextruded strips were determined on an RTM 100 Tensilon tensile tester at room temperature at a strain rate of $10^{-2} \mathrm{~s}^{-1}$. To avoid sample fracture at the clamps, tapes were glued between fine grained sandpaper strips before mounting in the tensile tester. The cross-sectional area of the samples was calculated from the sample length and weight, using a density of $0.97 \mathrm{~g} \mathrm{~cm}^{-3}$.

Thermally induced shrinkage measurements were performed on (coextruded) samples with a length of $20 \mathrm{~mm}$. The samples were immersed in a pre-heated silicone oil bath $\left(T=180^{\circ} \mathrm{C}\right)$ for approximately $10 \mathrm{~s}$. The molecular draw ratio $(M D R)$ was calculated from the measurements using equation (1):

$$
M D R=\left(L_{\mathrm{t}}-L_{\mathrm{s}}\right) / L_{0}+1
$$

In equation (1) $L_{0}$ is the original length prior to extrusion, $L_{\mathrm{t}}$ is the sample length after extrusion and $L_{\mathrm{s}}$ is the shrunken length.

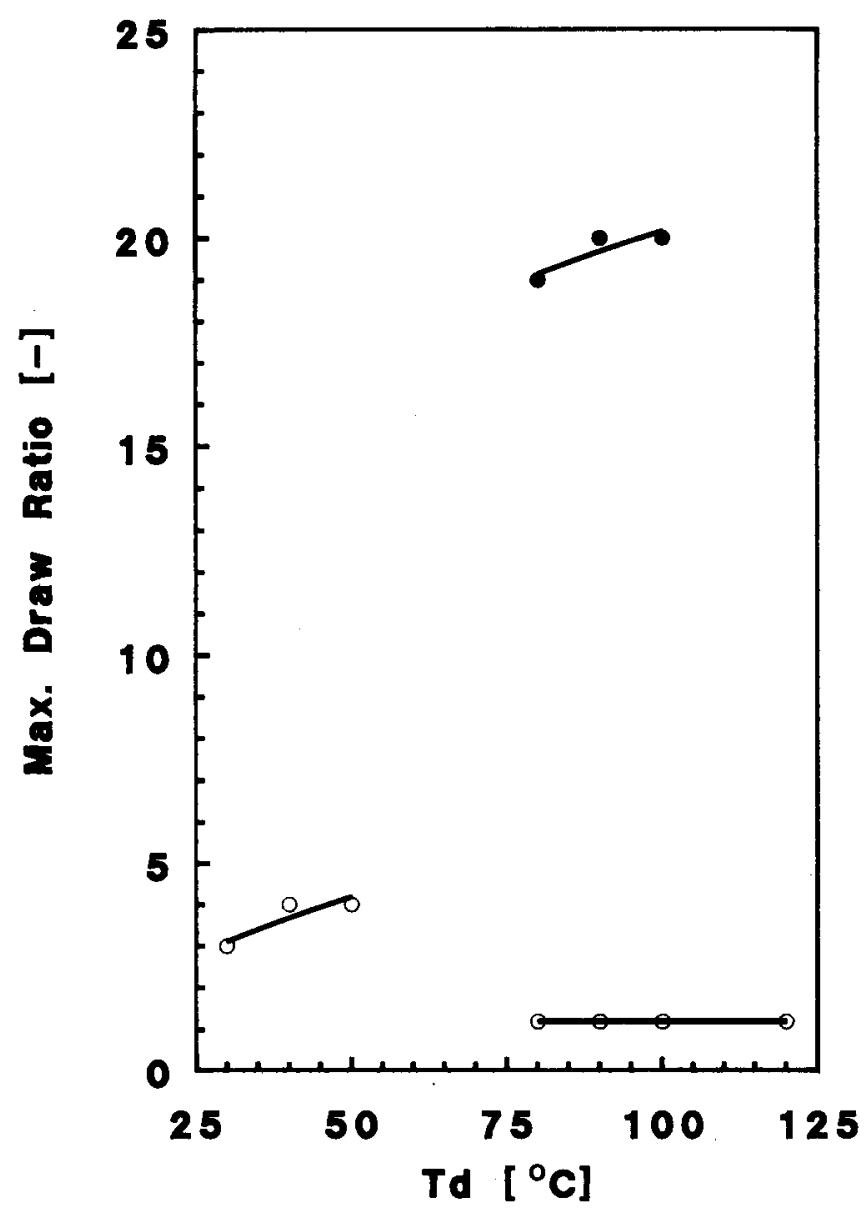

Figure 1 Maximum attainable draw ratio of melt-crystallized trans1,4-PB $(O)$ and HDPE $(O)$ as a function of drawing temperature $\left(T_{\mathrm{d}}\right)$

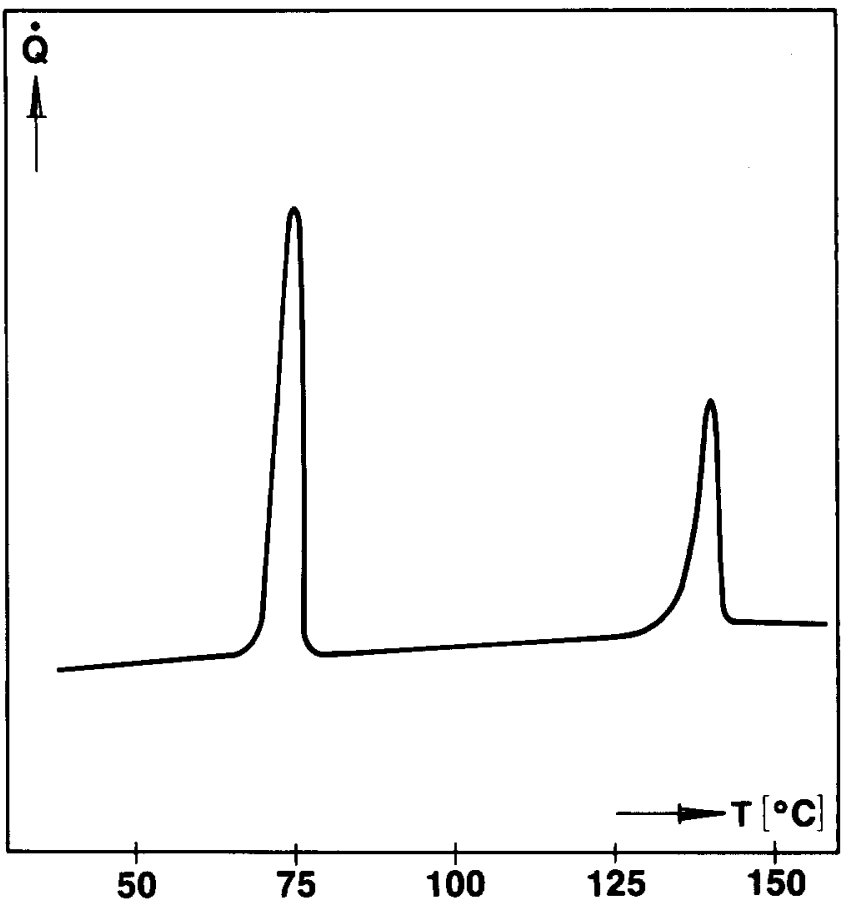

Figure 2 D.s.c. thermogram of melt-crystallized trans-1,4-PB

D.s.c. measurements were performed using a SeikoDenshi DSC-10 differential scanning calorimeter at a constant heating rate of $5^{\circ} \mathrm{C} \mathrm{min}-1$.

Wide-angle X-ray patterns were recorded with a flat-plate camera. WAXS patterns at elevated temperature were recorded using a Statton camera equipped with an oven. In both cases $\mathrm{Ni}$-filtered $\mathrm{Cu} \mathrm{K} \alpha$ radiation was used.

\section{RESULTS}

Tensile drawing behaviour of trans-1,4-polybutadiene in the solid state

The maximum attainable draw ratio of melt-crystallized trans-1,4-PB is plotted in Figure 1 as a function of tensile drawing temperature. The maximum attainable draw ratio of melt-crystallized trans-1,4-PB is rather low especially in the temperature region from 70 to $140^{\circ} \mathrm{C}$ $\left(\lambda_{\max }=1-2\right)$. At first sight this behaviour seems unusual, especially if the experimental results on trans-1,4-PB are compared with data of melt-crystallized HDPE possessing a similar molecular weight (Figure 1).

In Figure 2, a d.s.c. thermogram of melt-crystallized trans-1,4-PB is shown. A large endotherm is observed at approximately $65^{\circ} \mathrm{C}$, which in general is related to a first-order solid-solid phase transition to a hexagonal crystal phase ${ }^{14,15}$.

It was shown that high maximum attainable draw ratios cannot be obtained by tensile drawing of trans1,4-PB. Therefore we turned to solid-state coextrusion in order to produce highly oriented structures.

\section{Solid-state coextrusion of trans-1,4-polybutadiene single crystal mats}

The maximum attainable extrusion draw ratio $\left(E D R_{\max }\right)$ of coextruded trans-1,4-PB single crystal mats is plotted in Figure 3 as a function of extrusion temperature. This figure shows that high (extrusion) draw ratios can be 


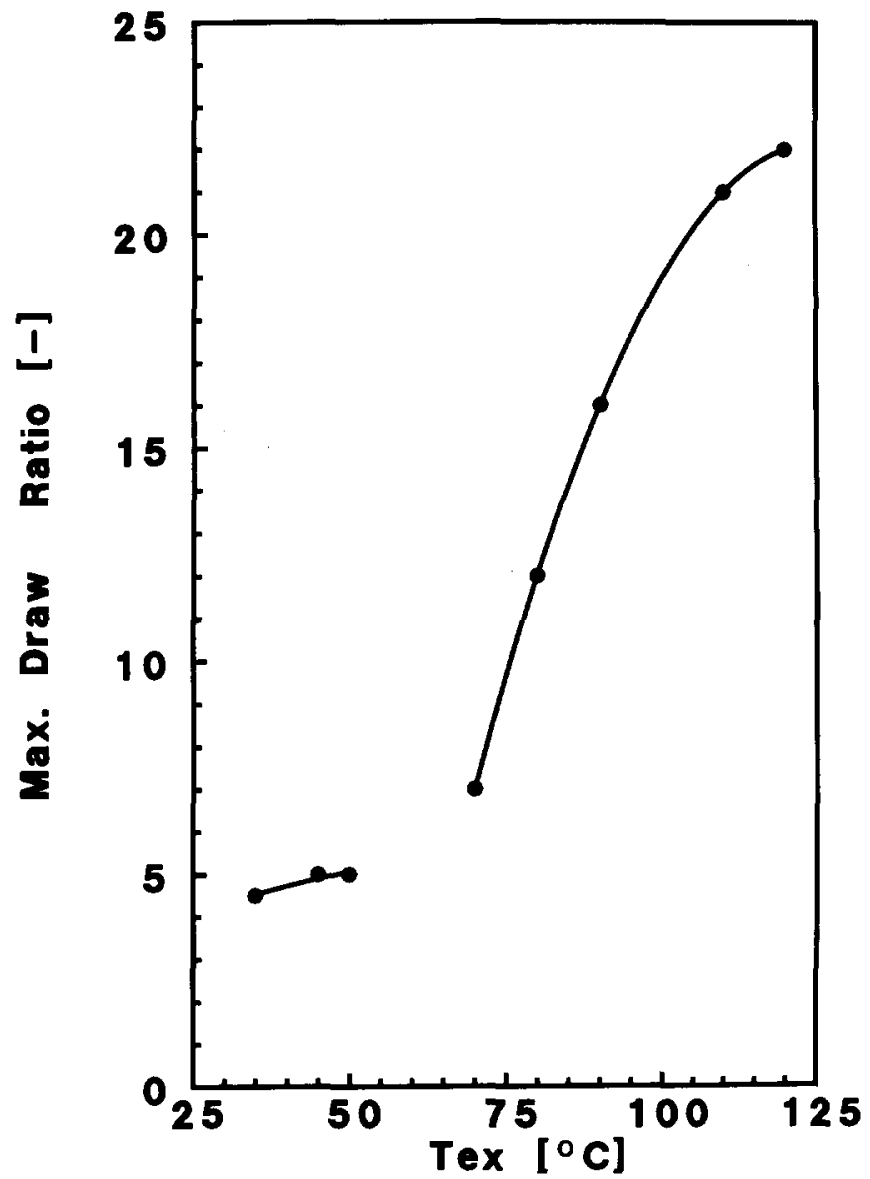

Figure 3 Maximum attainable draw ratio of trans-1,4-PB as a function of extrusion temperature $\left(T_{e x}\right)$

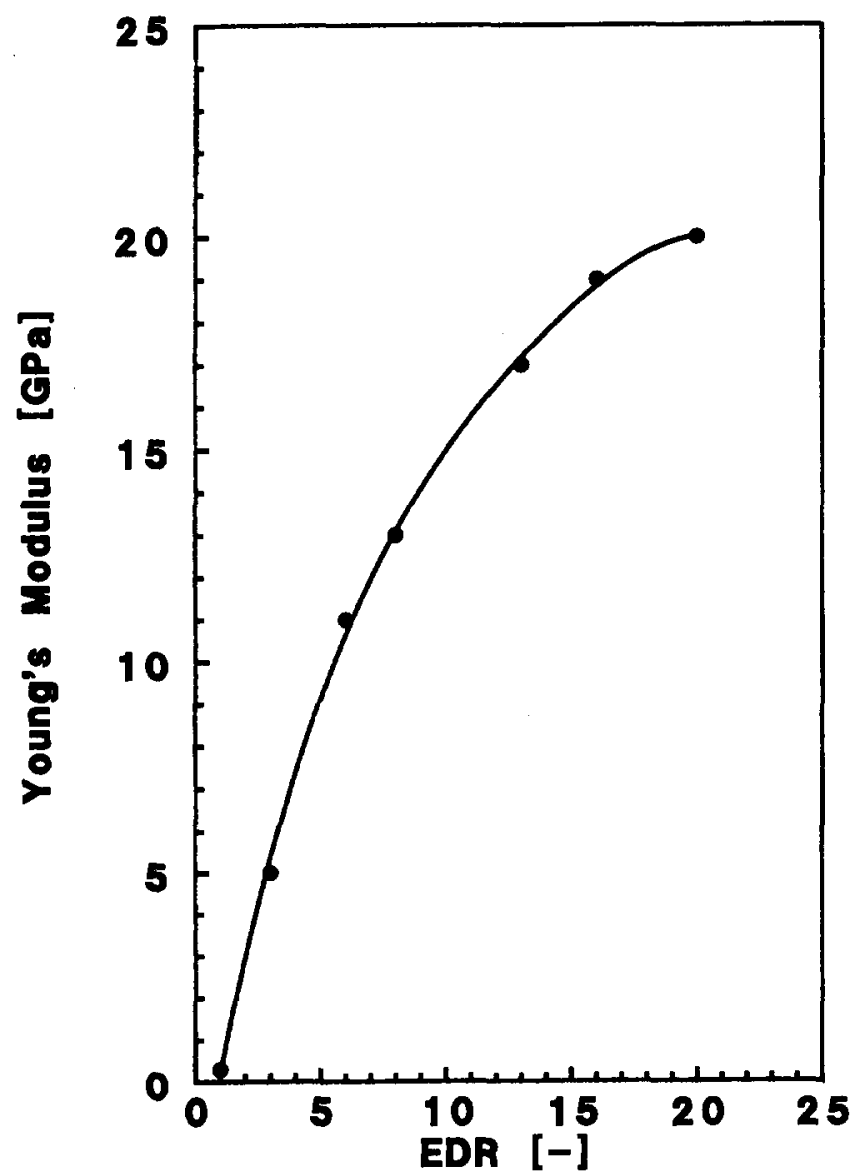

Figure 4 Young's modulus of coextruded trans-1,4-PB $\left(T_{\mathrm{ex}}=110^{\circ} \mathrm{C}\right)$ as a function of extrusion draw ratio $(E D R)$ obtained by coextrusion of trans-1,4-PB in the temperature region from 70 to $140^{\circ} \mathrm{C}$ (compare with Figure 1).

The Young's modulus and tensile strength of coextruded trans-1,4-PB are plotted in Figures 4 and 5 as functions of draw ratio. These figures show that structures with a modulus and tensile strength of respectively $\sim 20 \mathrm{GPa}$ and $\sim 0.4 \mathrm{GPa}$ can be obtained.

Experimental results of elastic recovery measurements are shown in Figure 6. The macroscopic extrusion draw ratio is compared with the molecular draw ratio as deduced from shrinkage measurements (see 'Experimental' section). Figure 6 indicates that coextrusion of trans-1,4-PB in the conformational disordered (condis) phase is highly effective in generating chain orientation/ extension.

In Figure 7 WAXS patterns, recorded at 20 and $100^{\circ} \mathrm{C}$, of coextruded trans-1,4-PB are shown. The WAXS patterns indicate that the samples are highly oriented in the extrusion direction and that the solid-state phase transition to the hexagonal phase is still present after coextrusion.

Post-drawing of coextruded trans-1,4-polybutadiene

In Figure 8 experimental results are shown of postdrawing experiments of trans-1,4-PB that was coextruded at $110^{\circ} \mathrm{C}$ to an extrusion draw ratio of 6 . This figure shows that the coextruded trans-1,4-PB single crystal mats cannot be post-drawn $\left(\lambda_{\max }<1.2\right)$ in the temperature region from 70 to $140^{\circ} \mathrm{C}$. Again, it is observed that it is impossible to draw trans-1,4-PB in the hexagonal crystal phase.

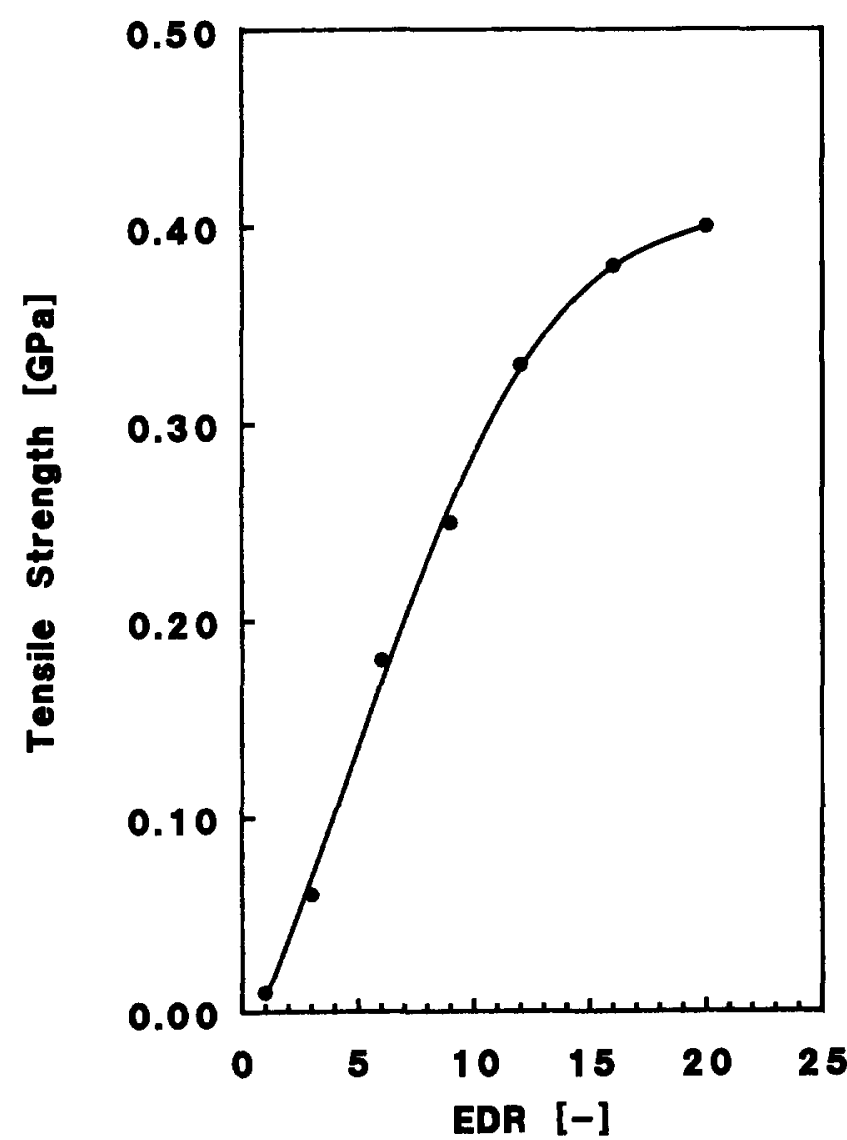

Figure 5 Tensile strength of coextruded trans-1,4-PB $\left(T_{\text {ex }}=110^{\circ} \mathrm{C}\right)$ as a function of extrusion draw ratio $(E D R)$ 
Deformation of trans-1,4-polybutadiene: N. A. J. M. van Aerle et al.

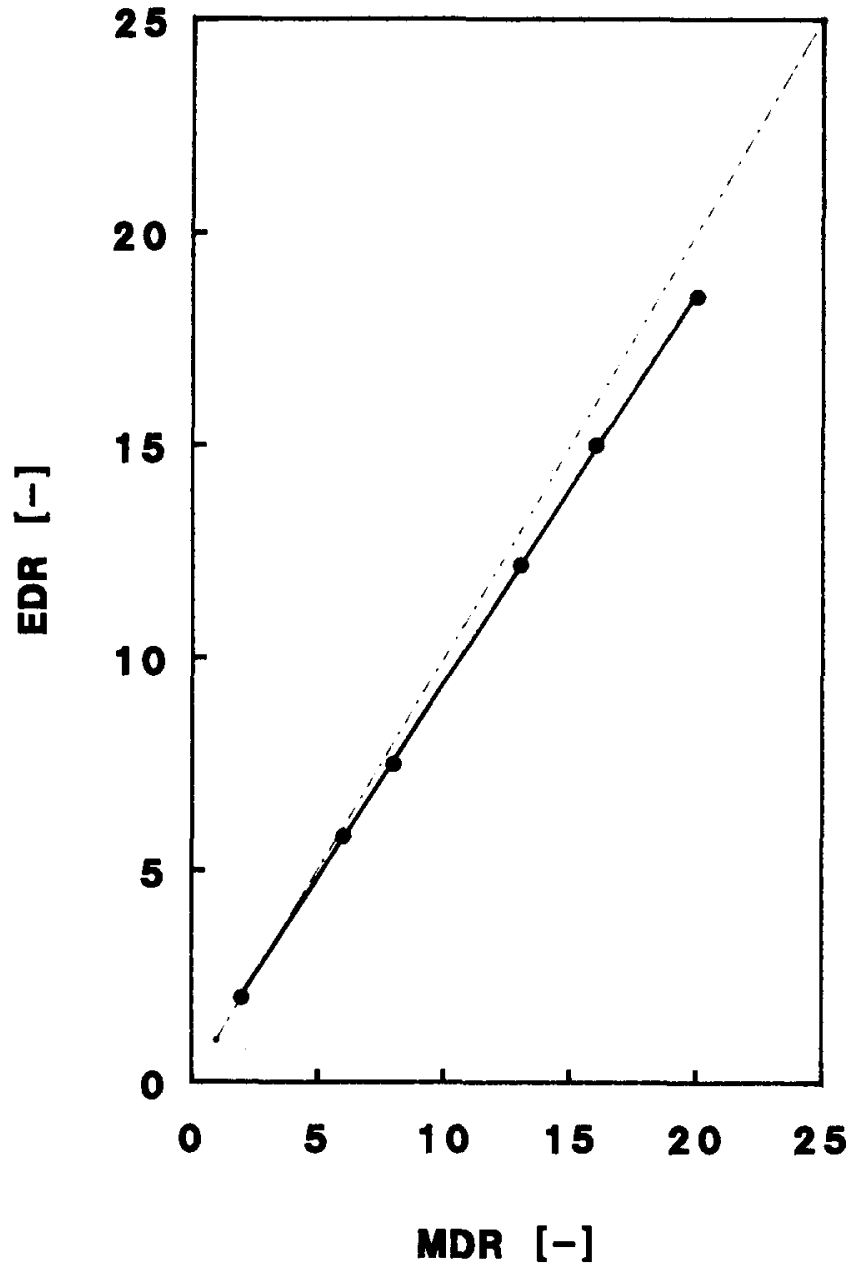

Figure 6 Molecular draw ratio $(M D R)$ of coextruded trans-1,4-PB $\left(T_{\mathrm{ex}}=110^{\circ} \mathrm{C}\right)$ as a function of extrusion draw ratio $(E D R)$

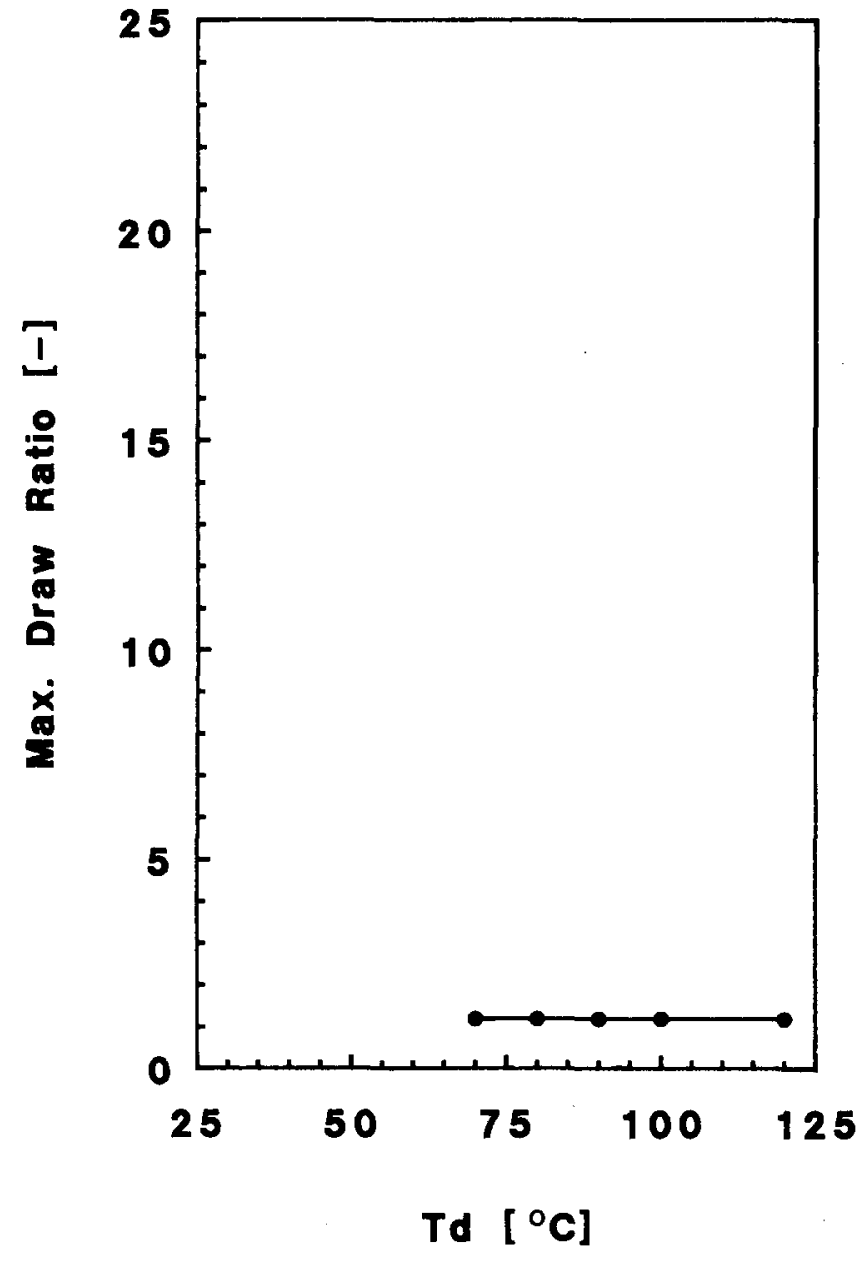

Figure 8 Maximum attainable draw ratio of coextruded trans-1,4-PB $(E D R=6)$ as a function of drawing temperature $\left(T_{\mathrm{d}}\right)$

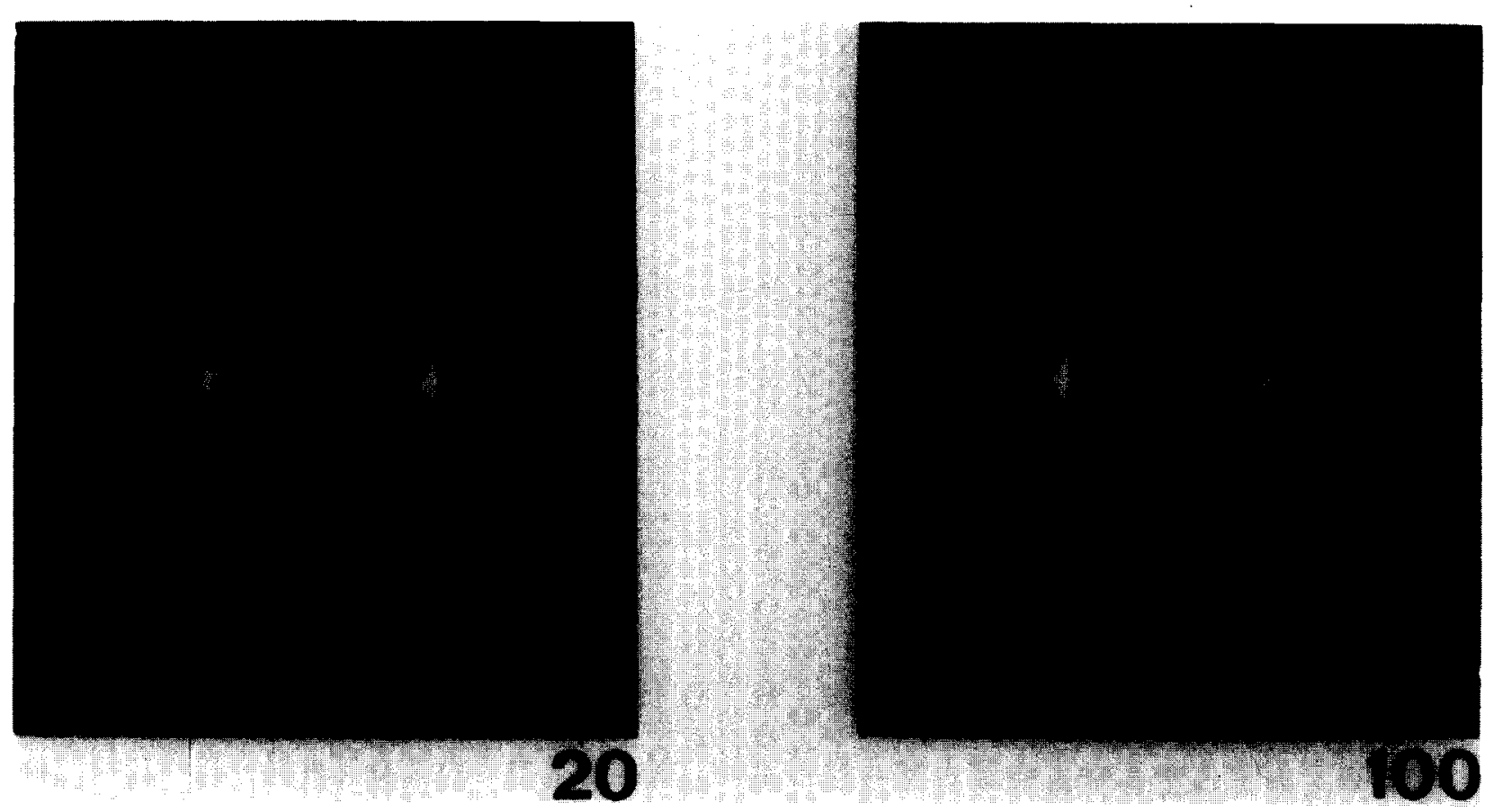

Figure 7 WAXS patterns of coextruded trans-1,4-PB $(E D R=15)$ recorded at $T=20^{\circ} \mathrm{C}$ and $100^{\circ} \mathrm{C}$ 


\section{DISCUSSION}

Trans-1,4-polybutadiene is a flexible, linear polymer with a dynamic conformational disordered (condis) pseudohexagonal crystal structure in the temperature region from $\sim 70$ to $\sim 140^{\circ} \mathrm{C}^{14,15}$. A condis crystal is considered to be a mesophase of linear, flexible macromolecules and has a macroscopic appearance in between a solid and a liquid $^{14}$

Under special conditions linear polyethylene also exhibits a conformational disordered hexagonal phase ${ }^{14,15}$, which is very similar to the condis phase of trans-1,4-PB. In previous studies it was already shown that ultra-drawn polyethylene fibres cannot sustain any applied stress in the hexagonal condis phase due to an increased molecular mobility ${ }^{16-19}$.

Melt-crystallized trans-1,4-PB cannot be deformed to high draw ratios via tensile drawing in the temperature range from 70 to $140^{\circ} \mathrm{C}$ (Figures 1 and 8 ). However, trans-1,4-PB can be coextruded in the hexagonal condis phase to high (extrusion) draw ratios (Figure 3). Premature sample failure is prevented during coextrusion by forcing the material through a conical die. Elastic recovery measurements indicate that the macroscopic and molecular draw ratios are virtually identical, which indicates that coextrusion in the pseudo-hexagonal crystal phase is highly effective in generating chain orientation/extension (Figure 6). Moreover, these measurements show that relaxation of orientation during or after coextrusion of trans-1,4-PB in the condis phase does not occur despite the high mobility in this phase.

The Young's modulus and tensile strength of trans1,4-PB increase significantly with increasing extrusion draw ratio (Figures 4 and 5). However, the maximum attainable Young's modulus and tensile strength is rather low (respectively $\sim 20 \mathrm{GPa}$ and $\sim 0.4 \mathrm{GPa}$ ) compared with, for instance, gel-spun ultra-drawn ultra-highmolecular-weight PE fibres ${ }^{1-3}$.

\section{CONCLUSIONS}

High-temperature uniaxial deformation of trans-1,4- polybutadiene is only possible via deformation processes involving extrusion and not via tensile drawing. This rather unusual behaviour is attributed to a solid-solid phase transition to a highly mobile pseudo-hexagonal conformational disordered crystal structure. Significant relaxation of molecular orientation during coextrusion in the condis phase does not occur. Consequently, highly oriented trans-1,4-PB tapes, with an enhanced modulus and tensile strength, can be produced. Moreover, the maximum attainable Young's modulus and tensile strength can probably be further increased by increasing the molecular weight of trans-1,4-PB.

\section{REFERENCES}

1 Smith, P., Lemstra, P. J. and Booy, H. C. J. Polym. Sci., Polym. Phys. Edn. 1981, 19, 877

2 Smith, P., Lemstra, P. J., Kalb, B. and Pennings, A. J. Polym. Bull. $1979,1,733$

3 Smith, P. and Lemstra, P. J. Polymer 1980, 21, 1341

4 Capaccio, G. and Ward, I. M. Nature (Phys. Sci.) 1973, 243, 143

5 Capaccio, G. and Ward, I. M. Polymer 1974, 15, 233

Capaccio, G. and Ward, I. M. Polymer 1975, 16, 239

7 Gibson, A. G., Davies, G. R. and Ward, I. M. Polymer 1978, 19,683

8 Gibson, A. G. and Ward, I. M. J. Polym. Sci., Polym. Phys. Edn. 1978, 16, 2015

9 Griswold, P. D., Zachariades, A. E. and Porter, R. S. Polym. Eng. Sci. 1978, 18, 861

10 Dijkstra, D. J. Ph.D. Thesis, Rijksuniversiteit Groningen, The Netherlands, 1988

11 Hikmet, R. Ph.D. Thesis, University of Bristol, 1985

12 Natta, G., Porri, L., Corradini, P. and Morero, D. Chim. Ind. 1958, 40, 362

13 Möller, M. Makromol. Chem., Rapid Commun. 1988, 9, 107

14 Wunderlich, B. and Grebowicz, J. Adv. Polym. Sci. 1984, 60/61, 1

15 Wunderlich, B., Möller, M, Grebowicz, J. and Bauer, H. Adv. Polym. Sci 1988, 87, 45

16 Lemstra, P. J., Bastiaansen, C. W. N. and Meijer, H. E. H. Angew. Makromol. Chem. 1986, 145/146, 343

17 Lemstra, P. J., van Aerle, N. A. J. M. and Bastiaansen, C. W. M. Polym. J. 1987, 19, 85

18 van Aerle, N. A. J. M. and Lemstra, P. J. Makromol. Chem. $1987,189,1253$

19 Bastiaansen, C. W. M. and Lemstra, P. J. Makromol. Chem., Makromol. Symp. 1989, 28, 73 